\title{
Methodological Aspects of Forming a Development Strategy for the Regional Socioeconomic System -Under Electronic Industry Enterprises in the Republic of Tatarstan
}

\author{
Gaziz Mingaleev ${ }^{1}$, Aleksandr Kushimov ${ }^{2}$, Nikolay Kolesov ${ }^{3}$, Nikolay Uraev ${ }^{4}$
}

\begin{abstract}
:
This paper considers the methodological aspects of forming a development strategy for the regional socioeconomic system (by the example of radio-electronic enterprises in the Republic of Tatarstan). The paper suggests a conceptual scheme of the macro-and microfactors' influence on the regional socioeconomic system. This scheme is based on the study of the market power of enterprise's contact persons (suppliers, competitors, and consumers) and subjects that have an indirect impact (government, markets, financial institutions, insurance companies, etc.). It has a hierarchic structure and allows coordinating the terms of cooperation for different elements of the socioeconomic system.
\end{abstract}

Key Words: Radio-Electronic Industry, Socioeconomic System, Strategic Plans, TargetSetting, Economic Resources, Management by Objectives, Regional Development Factors, Assets, Productivity, Operating Efficiency

\footnotetext{
1 Doctor of Economic Sciences, Professor, Department of Economics and Enterprise Management, Kazan National Research Technical University of A. N. Tupolev, 420111, Karl Marx Street 10, Russian Federation, Tatarstan, Kazan, kafedra@eupkai.ru

2 Doctor of Economic Sciences, Professor, Department of Economics and Enterprise Management, Kazan National Research Technical University of A. N. Tupolev, 420111, Karl Marx Street 10, Russian Federation, Tatarstan, Kazan, kafedra@eupkai.ru

3 Doctor of Economic Sciences, Professor, Department of Economics and Enterprise Management, Kazan National Research Technical University of A. N. Tupolev, 420111, Karl Marx Street 10, Russian Federation, Tatarstan, Kazan, kafedra@eupkai.ru

${ }^{4}$ Senior Teacher, Economics and Management of National Economy (regional economy), Department of Economics and Enterprise Management, Kazan National Research Technical University of A. N. Tupolev, 420111, Karl Marx Street 10, Russian Federation, Tatarstan, Kazan, kafedra@eupkai.ru
} 


\section{Introduction}

The paper builds a formation algorithm for the manufacturing program of radioelectronic enterprises. A peculiar feature of this algorithm is its focus on involving resources of the enterprise's external environment on terms that are acceptable to an economic entity. The paper also suggests stages of the development strategy for the regional socioeconomic system that are based on the principles of lean production, which assume the determination and market substantiation of the regional resource intensity limit of separate productions. This allows plotting an evolutionary vector for the transformation of the socioeconomic system into an adaptive structure with such properties as self-organization and self-regulation.

The achievement of economic and social results, which are planned for the current and future periods, in the management of regional economic development under considerable instability of the external environment depends on the cooperation of technological and resource-related elements, and on the efficiency of the regional development management system (Dooris, 2004). Observing the functional purpose and ensuring the focus of current, future, and strategic management systems on achieving planned results of socioeconomic regional development is possible within the framework of a management mechanism for the regional economic system as an instrument for improving qualitative and quantitative characteristics of the used management types' objectives. The latter is achieved by intensifying resource use, improving the organization of cooperation between elements, activating the organizational capacity, and expanding the range of competitive advantages of the regional socioeconomic system.

Solving the scientific problems of improving economic and social results of the regional economic management system by taking extensive measures for rationalizing the cooperation of each separate element and the structural parts of the regional production management system, using geopolitical, environmental, and infrastructural factors that influence the regional economic growth rate, counteracting the negative impact of instable external and internal environments, becomes especially relevant during the mitigation of the economic and financial crises' effects, given the low technological level of the fixed capital, unsolved problems of improving investment and innovation attractiveness of the regional economy, insufficient growth rate of the economic performance (gross regional product), compared to the growth rate of aggregate production costs, and discrepancy between the levels of production growth and salaries (Goodstein, 1993). It is possible to improve the economic and social results of the current operation and future development of the regional socioeconomic system by forming and taking comprehensive measures within the framework of the mechanism for rationalizing the cooperation of elements of a regional production management system that are aimed at improving the organizational structure, ensuring the balance between available resources and set future objectives for economic and social results, observing the functional purpose and objective orientation of technological and 
resource-related elements of the management system of the regional socioeconomic development (Hill and Jones, 1992).

The solution of the following scientific problems is also relevant: estimating the economic result and efficiency of the management system for the development of the regional socioeconomic system, and the mechanism for the cooperation of its elements, based on the determination of the influence level of current, future, and strategic management on the economic and social result with a subsequent correlation of the economic result with the expenditures on taking measures within the technological elements of the management system; predicting the achievement of the planned economical regional result, which is an objectification factor for determining the level of using own resource and organizational capacities with a view to ensuring necessary rates of economic growth under the conditions of unstable external and internal environments.

Under modern conditions, Tatarstan industrial enterprises that aim to keep their share of the market face the need to determine the trends and factors of the external environment's influence, alongside the study of internal processes of the enterprises. Timely reaction to challenges of the external environment and preventive actions can help avoiding an unwanted course of events and ensuring the enterprise's survival under globalization and growth of production scale, which is a relevant modern problem. Radio-electronic enterprises of the Republic of Tatarstan (RT) are a spatially distributed regional socioeconomic system that has common strategic objectives, and are included in the structure of the Russian radio-electronic industry.

The relevance and practical demand of the national economy, radio-electronic enterprises, and branch-specific constituents of the regional economy for improving economic and social results of the management system of the regional socioeconomic development determined the objective, tasks, and subject of this research.

The practical value of this paper consists in the ability to use its recommendations regarding the concept of regional development of the socioeconomic system within the framework of radio-electronic enterprises in RT and other regions of Russia, regarding the mechanism structure of cooperation between federal, regional, and municipal executive institutions, the Rostec (formerly Rostekhnologii) state corporation and radio-electronic enterprises, and apply the principles of Japanese management (Dao Toyota) to develop the socioeconomic system within the framework of the RT radio-electronic enterprises' activity that is aimed at increasing the value to the consumer and steadily reducing production costs, forming production programs for radio-electronic enterprises, under the execution of State Defense Order and production diversification.

This paper significantly updated the methodological aspects of improving the competitiveness of regional socioeconomic systems by applying M. Porter's 
competitive advantage theory that allows forming and developing competitive advantages of individual regional productions.

\section{Methods}

The study applied:

- The systematization method that that consists in the division of studied phenomena, based on the tasks of the study and selected criteria, into classes that are characterized by a certain commonality and peculiar features (classification, typology, specialization, concentration, etc.);

- The economic and geographical research method that includes the regional method (study of the ways of territorial formation and development, the examination of the development and arrangement of productions in the regional development), the branch method (study of the ways of formation and functioning of economic branches in terms of geography, examination of the development and arrangement of productions by branches) and the local method (study of the ways of formation and development of local productions, examination of the development and arrangement of productions by its elementary cells);

- The economic and mathematical modeling method that includes modeling territorial proportions of the economic development of Russia, modeling the arrangement of the economy by branches, and modeling of the formation of economic regional complexes;

- The regionometrics methods (regionometrics is a scientific field in regional economics that studies the application of mathematical methods);

- The taxonomy method - the division of territories into commeasurable and hierarchically superordinate taxons. Taxons are equivalent and hierarchically superordinate subnational entities, e.g. administrative areas (Grebenkina, 2014);

- The variant method of allocating regional production capacities. This method is mostly used when designing schemes for arranging production across the territory of the region during the first stages of planning and prediction. It involves studying variants of different development levels of this or that region's economy, and variants of territorial economic proportions by regions;

- The methods of correlating regional living standards of the population and predicting the development of the regional social infrastructure.

\section{Literature Survey}

The issues of strategic development of the production and economic activities of 
enterprises in various industries are considered in a wide range of works by such authors as Thompson and Strickland (1990), Lubashev (2013), Matraeva (2012) and others.

The issues of improving economic growth by upgrading the socioeconomic systems are considered in the works of many scholars, including Porter (1990), Schoemaker (1995), Garifullin (2014), Malsagov and Mironova (2013), Malsagov (2013), Beerel (1998), Clemons (1995) and others.

A valuable contribution to this area was made by experts J. van Dujin (1972), Schumpeter (1934), Pries and Janszen (1995), Alfred (1969), Aguilar (1967) and others.

A certain contribution to the study of theoretical issues in separate areas of the problem was made by scientists Neveykina (2013), Oveshnikova (2013), Rudenko (2014), Archibugi and Michie (1997), Reading (2002), Hutt, Walker and Frankwick (1992) and others.

Studies are lacking regarding the methodological aspects of forming a production development strategy at Russian radio-electronic enterprises under modern conditions that are characterized by certain possibilities for development (expected growth of the state defense order), threats (the difficulty of completing a growing state defense order and the cancellation of import-related barriers before the completion of the technical re-equipment and research and development), and risks (branch-specific, social, country and regional, financial, legal) (Piercy, Harris, Peters, 1997).

On the one part, the lack of studies and the insufficient development level of methods for strategic planning at radio-electronic enterprises, taking into consideration the peculiarities of the current state of events, and on the other part, its scientific and practical value determined the subject of this paper and allowed defining the objective, tasks and scope of issues under study.

\section{Research Results}

The objective of the research was to design methodological aspects of forming a development strategy for the regional spatially distributed socioeconomic system under modern conditions. The scientific novelty of the paper consists in the design of methodological recommendations for forming a development strategy for the regional spatially distributed socioeconomic system that involve the application of the systems method with a view to improving production processes at enterprises, ensuring extended reproduction, organizing rational cooperation between its participants, and distributing resources among them. The authors designed a conceptual scheme of the macro- and micro-factors' influence on the regional spatially distributed socioeconomic system. This scheme takes into consideration the 
complex of specific peculiarities of radio-electronic enterprises' operation, and allows coordinating the terms of cooperation for different participants of production processes.

A clear vision of the constituents and structure of an enterprise's production program for a certain period is a key element of the development strategy for the regional socioeconomic system. In order to achieve this, the author suggested an algorithm of forming a production program for radio-electronic enterprises with the following distinguishing features:

- demand orientation that is expressed in the consideration of existing, potential and hidden needs of clients in terms of the correlation between cost and quality, volume of the order and discount amount (Sorvina, 2013);

- maximum return of internal resource use, particularly, due to the use of efficient organization of production processes, the use of time management and lean production technologies, production automation and mechanization means, and technical and technological re-equipment;

- timely interaction with the external environment, the search and involvement in production processes of the enterprise's external environment resources, such as borrowed and called up capital (financial lease and leaseback, credit, private-public partnership, additional emission of shares, bonds placement, insurance, etc.), temporary personnel policy (recruiting and leasing of personnel, out staffing, etc.), the use of external objects and means of labor (rent, operating leasing, outsourcing, consulting, engineering, etc.), the use of various intellectual property assets (purchase of patents, franchising, joint research and development, creation of common use centers, cooperation between higher education institutions and research institutes, the attraction of various level grants, venture investment, etc.).

The algorithm of forming a production program for radio-electronic enterprises is presented in Figure 1.

The main condition for applying the algorithm is the discrepancy between the growth rate of demand for radio-electronic products and the enterprise's productivity dynamics. The suggested algorithm is based on the procedure of choosing a planning model for the production program. At that, it is necessary to consider the tasks that have to be completed in order to ensure the formation of the output program.

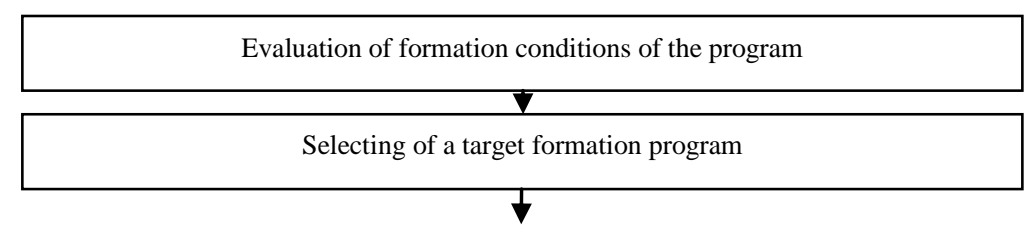




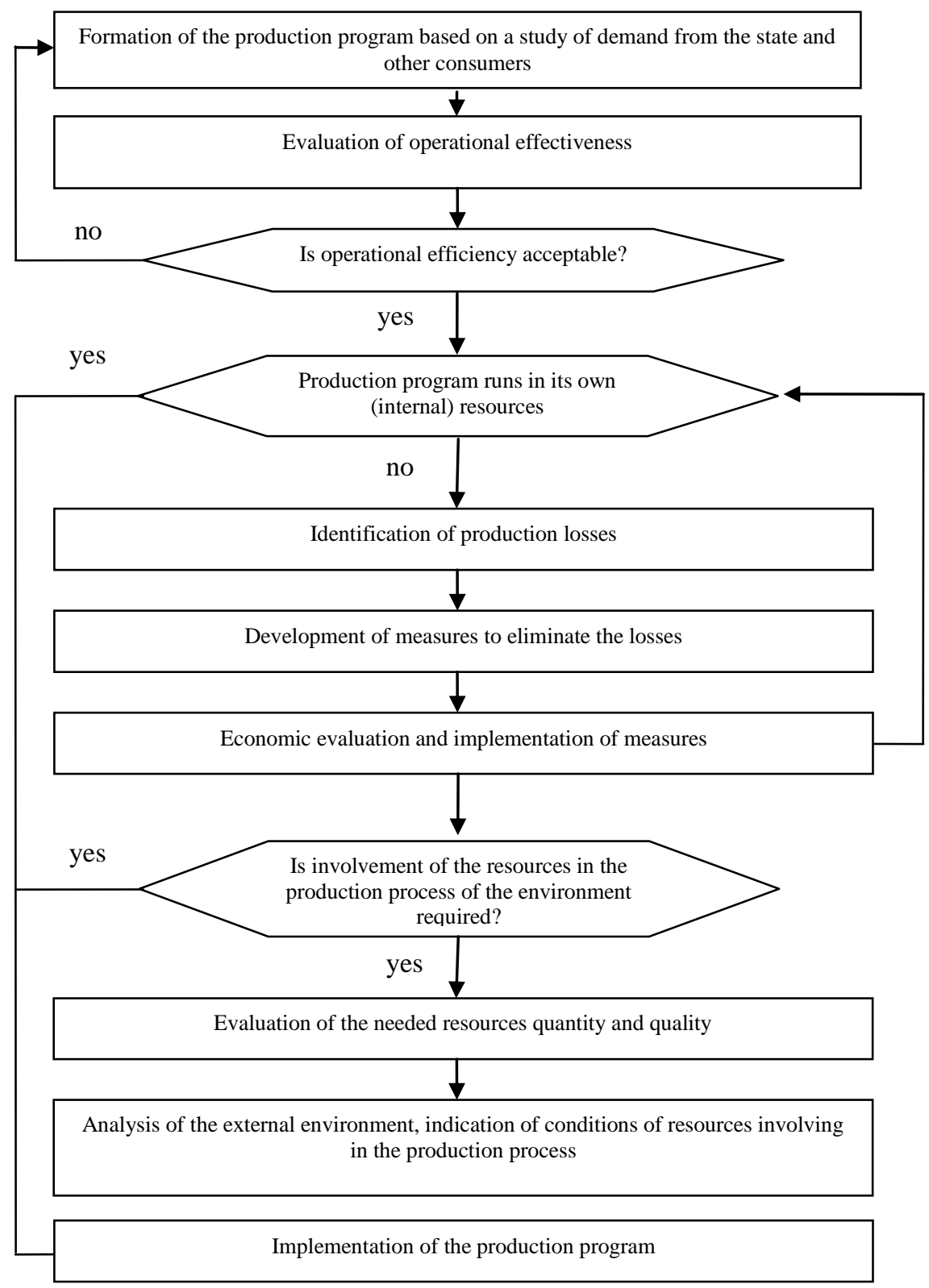

Figure 1. The algorithm for generating the production program of the enterprise electronic industry

Assessing the conditions of forming radio-electronic enterprises' production program allows tying in the goals of its formation with the tasks of the regional socioeconomic policy. At that, the main goals are: 
- reduction of the need for own circulating assets;

- reduction of production's dependence on borrowed capital;

- maximization of output at a determined level of own funds sources;

- ensuring maximum continuity and best production rhythm;

- freeing sources of funds for production upgrading and assortment updating.

As previously noted, if the production is characterized by significant resource intensity and fluctuations of income amounts, it is efficient to use the model for determining target costs for satisfying consumer needs that allows comparing the values for specific solvent consumers and the aggregate production costs. If the enterprise is characterized by a high risk of insufficient production capacities to execute the target production program, it is expedient to use the model that allows both the efficient use of own production capacities and the maximum use of resources from the external environment with a view to achieving certain goals (Tazhitdinov, 2013).

Using the considered algorithm of forming a production program is expedient for assessing products that constitute a considerable share in the enterprise's sales. If according to the assessment results the target production program is not demonstrating an adequate operating efficiency, an analysis is performed for the possibility of its improvement by correcting (modifying) the volumes and structures of production. In this case, one can emphasize a set of production programs that correspond to the operation of the enterprise under various unfavorable conditions: decrease of demand, increase of the products' financial cycle, and increase of fixed costs. Since it is known beforehand, which conditions may be realized, the correction of the production program should be made with a view to increasing its adaptability in relation to changes in parameters of the external environment.

According to analysis results, a decision can be made to correct the obtained production program or keep the initial optimal production program. If the initial program turns out to be inadequate, its risk level unacceptable, and its improvement impossible, the main limitations should be reconsidered, or new models of forming production programs should be used. A peculiar feature of this algorithm is the focus on using resources from the enterprise's external environment on terms that are acceptable to this economic entity. In order to execute a certain production program that is substantiated in terms of operating efficiency, this algorithm involves the study and realization of primarily internal reserves for improving the efficiency of resource use by the production system, by applying methods and technologies of lean production, and involvement of resources from the external environment in the required amount and quality on acceptable terms.

The formation of production development strategies at radio-electronic enterprises requires a distinct sequence of actions that should have adequate methodological support, and focus on a certain result (Figure 2). Each stage can include the 
selection, improvement and application of methods that are aimed at providing specific results.

The first stage involves studying the consumer properties of products, determining the current and potential demand for specific types of products for each category of potential buyers. Special attention is paid to consumers' preferences and demands, which are ranked by their importance. This stage should provide the following results: distinct determination of products' competitive advantages, substantiation of the production program's structure for the period, elaboration of quality parameters that can provide the greatest demand for the products, increase of the enterprise's income. In order to achieve these results, it is possible to apply the following methods: questionnaire, SWOT analysis, prediction, the method, based on moving averages, $\mathrm{ABC}$ analysis, structuring of quality functions, the General Electric matrix. 


\section{Philosophy of a long-term prospect}

Stage 1. Research of consumer properties of products, determination of current and perspective requirement in the certain types of products

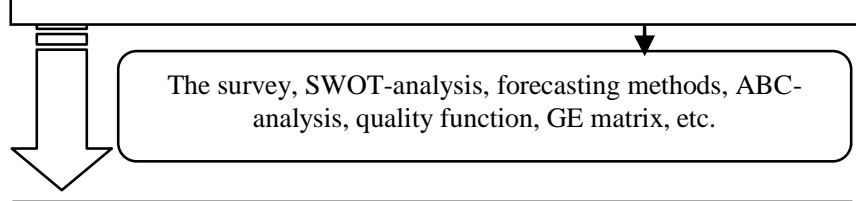

Stage 2. Determination of having a special purpose level of expenses at the required quality

$\begin{aligned} & \text { Functionally-value analysis, the method of quality function, } \\ & \text { target costing, etc. }\end{aligned}$
A correct process gives correct results

Stage 3. Estimation of the resources used in a production, and also resources that can be engaged in a productive process

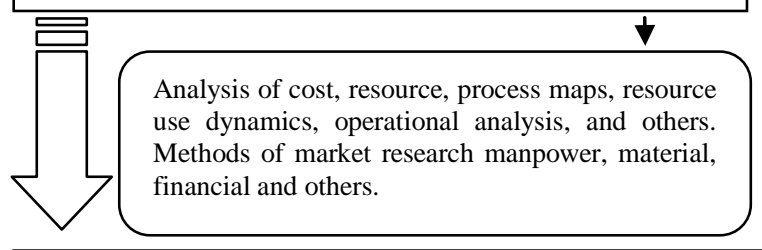

Stage 4. Research of productive process

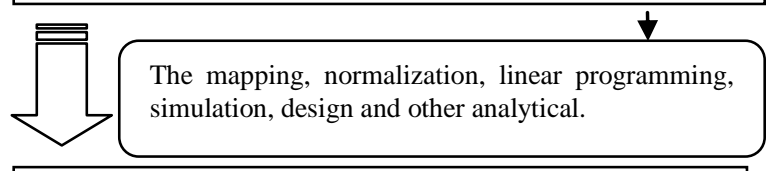

Stage 5. Development and economic evaluation of events on the removal of productive losses

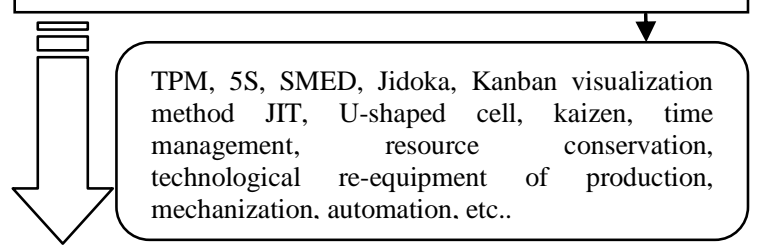

Stage 6. Development and introduction of the system of continuous perfection

Delegating, TQM, technology staff development, teambuilding methods, rotation, self-diagnostics, built-in quality, self-management, time management, reengineering and other.

Business Intelligence, PR-Technologies, Information Technology, SMART-technology, advertising, service, forecasting, etc.
Advantages of products, the target structure of productionstvennoj programs-wequality settings

The marginal cost of each type of resource for the production of a specific product

The long-term structure of resource to perform the targeted production program.

Productive losses, possible limits of change of parameters of production.

Variants of development of the productive system depending on the critical factors of success

Production system with properties of self-development and self-

regulation. 
Figure 2. Stages of the development of regional socio-economics system (on example of electronic industry enterprises in the Republic of Tatrstan)

The second stage determines the amount of production costs that provides a comparative advantage in relation to similar products that either are produced by competitors or may be offered by potential competitors. This stage has to include the determination of a costs structure for each type of resources that are used during the production and sales. In order to achieve these results, one can apply the following methods: value analysis, direct costing, target costing. This stage has to determine the limit for production costs for each type of products.

The third stage assesses the resources that are used in production, and resources that may be involved in production. The study of reserves for reducing the production cost of one product unit and their sale should reduce the prime cost of products, which will allow the enterprise to keep and expand its share of the market. At this stage, it is possible to apply the following methods: calculation of costs for each nomenclature unit, resource saving and resource replacement, analysis of process sheets, CVP analysis, outsourcing, outstaffing. This stage has to result in the determination of the reserve for improving the resource efficiency of the target production program.

The fourth stage involves the study of the production process with a view to using all production capacities and achieving maximum productivity, which is aimed at revealing imbalance in value creation during the transformation of resources, and detecting "bottlenecks" and problematic zones. In this case, it is possible to use the methods of charting, normalization, analysis of the production cycle duration, linear programming, time and motion study, etc. This stage should result in the detection of wasted production, and determination of possible changes to the production process parameters.

The fifth stage involves the design and economic assessment of measures that are aimed at eliminating waste. The suggested methods include the vast range of lean production instruments (TPM, 5S, SMED, Jidoka, Kanban, visual control, just-intime practice, U-shaped cells, Kaizen), which showed good results at various enterprises, and modern technologies for improving the production organization at the enterprise (time management, resource saving, technological re-equipment of production, mechanization, automation). This stage should provide alternative options for developing the production system, taking into consideration the variation of critical factors of success, such as productivity, adaptability, satisfaction, development, and survival. The substantiation of the scale and number of methods, as well as the costs of their implementation, is performed, depending on the set of selected critical factors of success.

The sixth stage involves the design and implementation of the continuous improvement system for the enterprise, including the production processes, 
personnel, technologies, service, quality, etc. Special attention should be paid to creating conditions for the realization of creative potential that ensures the high quality and speed of production, prevention of possible errors, visualization and timely solution of existing and potential problems during production by fostering team spirit and corporate culture. The following methods are used: delegation, TQM, technologies of personnel development, teambuilding, rotation, self-testing, built-in quality, self-management, time management, re-engineering, etc. This important stage should result in the creation of a self-regulating and self-developing production environment.

The seventh stage forms a system of preventive reaction to changes in the external environment, which should ensure the economic security and future competitiveness of the enterprise, taking into consideration the world trends in market development. The key elements of this system should be the ability to predict the needs and preferences of consumers, the readiness for international cooperation and differentiation during the production of high-technology products, and a radical change of production, sales and services parameters, as well as an increase of the products' functionality and quality. Various methods may be used during the execution of this stage, including business intelligence, PR technologies, information technologies, neuro-linguistic programming, SMART technologies, commercials, service, prediction of scientific progress, etc. This stage should result in the design of means, technologies, mechanisms and levers of influence on the external environment, as well as means of protection from the external conditions' negative impact.

Carrying out the strategy for developing enterprises of the radio-electronic industry as a regional socioeconomic system, the formation whereof is based on the application of resource and management by objectives approaches, allows specifying the interpretation of the "trans-regional production system" category. At the branch level, it is interpreted as a constituent of the hierarchal system of resource transformation for designing and producing competitive products. At the enterprise level, it is interpreted as a set of subsystems: organization and servicing of workplaces; organization of production; organization of equipment maintenance and repairs; organization of storage facilities; organization of transportation facilities, etc. Applying the suggested methodological instruments allows performing a targeted search and realization of reserves for increasing the efficiency of production resources' use, which improves the mobility, flexibility, and stability of the production system.

\section{Discussion}

Nowadays, lean production is becoming more common among Russian industrial enterprises, in the service sector, banking sector, Russian Railways, etc. Educational programs of trans-regional importance are being carried out (Cherkasov, 2014). For 
example, the leaninfo.ru information portal created an innovative service that it useful for studying lean production - a map of lean production distribution in Russia (Figure 3).

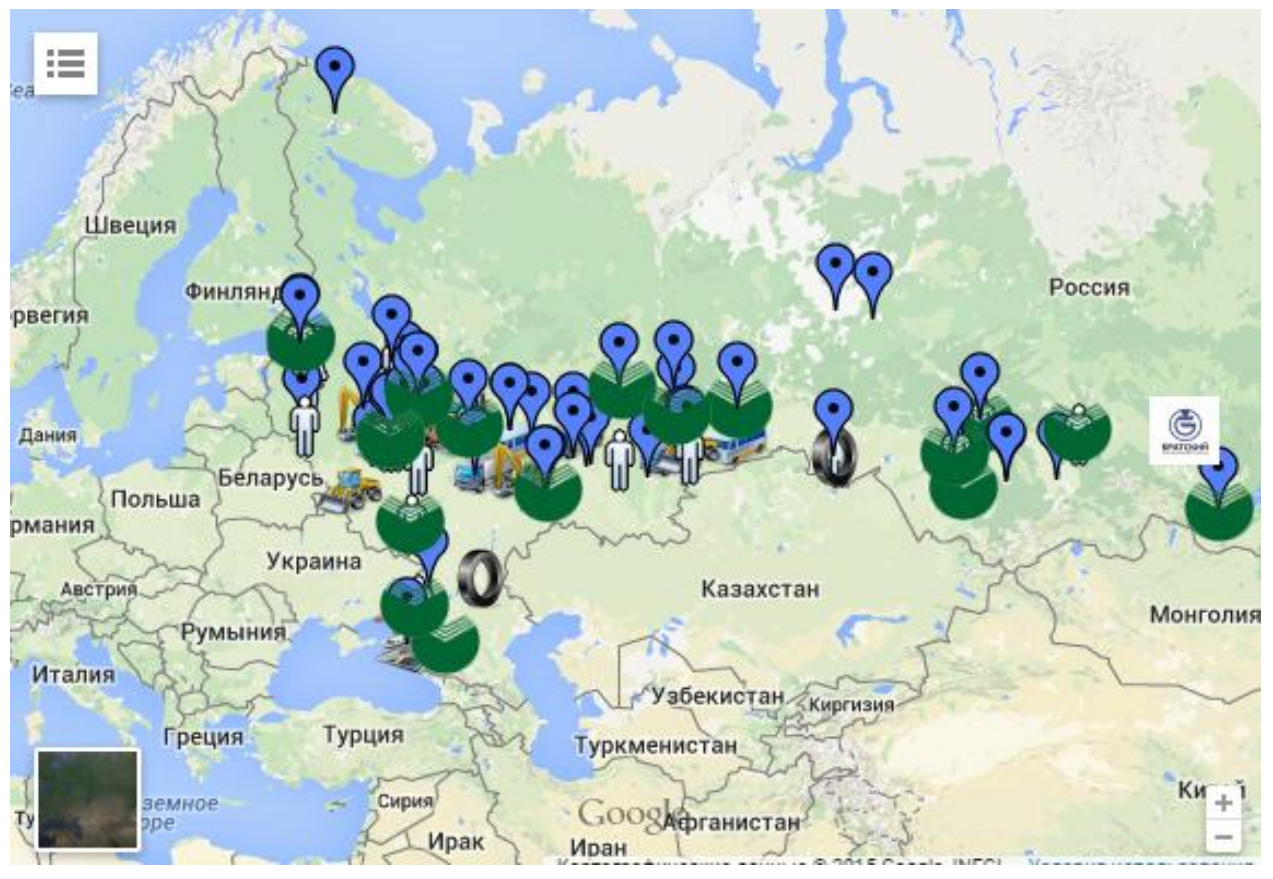

Figure 3. Map of lean production distribution

The practice of lean production implementation of one-third of the enterprises is mostly limited to the application of 1-2 instruments, which limits their cost saving. Large-scale works for implementing lean production are performed by less than 5\% of enterprises. The most significant tendency to apply lean production practices is demonstrated by large mechanical engineering and ferrous metallurgy enterprises, located in the Ural and Volga Federal Districts. The application of lean production affects the "bottlenecks" of enterprises. The most significant "bottlenecks" of enterprises that apply lean production are personnel motivation and design of new products. One of the requirements for further extension of lean production distribution in Russia is raising awareness of lean production instruments and the methods of their implementation in production.

In the Republic of Tatarstan, in accordance with the Decree of the Cabinet of Ministers of the Republic of Tatarstan No. 524-R dated 05.04.2010, the Ministry of Industry and Trade of the Republic of Tatarstan, and "Kazan National Research Technical University named after A. N. Tupolev" Federal State Budgetary Educational Institution of Higher Professional Education (KNRTU-KAI) are launching projects for lean production at mechanical engineering enterprises of the 
Republic of Tatarstan:

- drafting educational programs, curriculums, textbooks on lean production for students of higher education institutions and secondary vocational education institutions, within the framework of creating a trans-regional distributed resource center, designing a draft program of the "Lean production technologies" professional module for secondary vocational education institutions' graduates;

- designing interuniversity approaches to updating skills and consulting in the field of lean production;

- signing partnership deals in the field of vocational education, professional training, retraining, and skills updating of personnel between KNRTU-KAI and "Kazan Motor Production Association" OJSC, "Kazan Aviation Production Association named after S.P. Gorbunov" JSC, "KVART" CJSC, "Kazan Electrical Engineering Plant" JSC, "Sergo Plant" Production Association" Federal State Unitary Enterprise, "Zelenodolsk Plant named after A.M. Gorky" JSC, "Kazan Helicopters" JSC, "Povolzhsky Plywood and Furniture Factory" LLC, and "Zelenodolsk Plywood Factory" JSC;

- performing works with enterprises and organizations of the Republic of Tatarstan for providing services of advanced professional training for employees of enterprises and organizations that are restructuring and modernizing production in accordance with the lean production investment projects, top, middle, and low level managers, and specialists in direct economic contracts.

"Kamaz" JSC is the Russian enterprise that is the most active in implementing the lean production system. Its success is massive. Each ruble of costs is accounted for by more than a hundred rubles of income. However, such success was only made possible by mass involvement in the processes of both production personnel and managers. Before involving the personnel, the enterprise has to train them, but training all the personnel is only possible on the job. In the crisis period, almost any enterprise can find time for training without interrupting the production rhythm.

The main objective of the authors was to formulate the bases for sharing the international experience in lean production organization at the regional level.

\section{Conclusion}

The most important scientific results that were obtained by the author, and that determine the scientific novelty and value of the conducted research include the following:

In order to use opportunities and reduce the impact of threats, the activity of radioelectronic enterprises has to involve a constant study of market demands, search for 
profitable forms of investment and new means of bringing products to the market, applying new equipment and technologies with a view to maintaining financial stability and improving the efficiency of the enterprise's activity. The amount of income from products sales can be used as a criterion during production planning. It allows assessing the ability of the production program to provide additional influx of funds. Under the study of theoretical aspects of designing a development strategy for production, a conceptual scheme of the macro- and micro-factors' impact on the enterprise's production system was suggested, which takes into consideration the specific peculiarities of radio-electronic enterprises' operation, and allows coordinating the terms of cooperation for different participants of production processes. An algorithm was built for the formation of radio-electronic enterprises' production programs. Its distinguishing feature is the focus on involving resources of the enterprise's external environment on terms that are acceptable to an economic entity. This algorithm involves the study and realization of primarily internal reserves for improving the efficiency of resource use by the productions system, by applying methods and technologies of lean production, and involvement of resources from the external environment in the required amount and quality on acceptable terms.

The current state and organizational structure of the Russian radio-electronic industry, particularly, "KRET" JSC, was analyzed. The concern's positions in the market are relatively stable, but they are secured by only the governmental protection from import. The overall competitiveness of products is extremely low, both in terms of their price (higher or equal to import counterparts) and quality, and in terms of their engineering level, performance characteristics, and ergonomics.

The concern is almost absent from the civilian measuring instrument sector of the domestic market. The capacities and external environment threats of "Plant "Elekon" JSC were assessed. The assessment showed that the increase of the order for defense products is the first possibility in the ranking - it is highly probable in the near future. The most significant threats include the price pressure of consumers/clients (it is exerted constantly, and has a constant impact on the reduction of income), and the increase in the number of competitors in the household radio-electronic appliances sector. Both these factors are major in terms of their stage of involvement, and defining in terms of their power. In order to eliminate the threat of price pressure, it is necessary to design reliable methods of price formation (the lack thereof is considered an important factor), improve the operating productivity, and determine internal strategic focal points. The threat of an increasing number of foreign competitors in the production of household radioelectronic appliances is considered significant due to the lack of adequate strategies.

\section{References}

Archibugi, D. and Michie, J. (1997), “Technological Globalization and National Systems of Innovation” (Bath, Somerset: Future). 
Beerel, A. (1998), "Leadership through Strategic Planning" (Stamford, Connecticut: Thomson Publishing Inc.) p. 285.

Břečková, P. and Havlíček, K. (2013), "Leaders Management and Personnel Controlling in SMEs", European Research Studies Journal, vol. XVI, special issue, 3-14.

Cherkasov. V.V. (2014), "Industrial Modernization Methodology, Based on the Development of Russian Enterprises' Scientific and Technological Potential", State University of Management Bulletin 21: pp. 71-81.

Clemons, E.K. (1995), "Using Scenario Analysis to Manage the Strategic Risks of Reengineering", Sloan Management Review 36 (4).

Dooris, M.J., Kelley, J.M. and Trainer J.F. (2004), "Successful Strategic Planning" (New York, NY: Wiley Periodicals) p. 141.

Garifullin, I. (2014), "The Main Trends of the Innovation Potential Development in the Russian Economy", Proceedings of International Conference on Applied Economics (ICOAE), WSEAS / NAUN International Conferences, Greece.

Goodstein, L., Nolan, T. and Pfeiffer, J.W. (1993), “Applied Strategic Planning” (New York, NY: McGraw Hill) p. 379.

Grebenkina, Y.N. (2014), "Managing Regional Competitiveness: The Theoretical and Methodological Aspects" (Voronezh: Voronezh State University) p.160.

Hill, C. and Jones, G. R. (1992), "Strategic Management” (Boston: Houghton Mifflin).

Hutt, M.D., Walker, B.A. and Frankwick, G. L. (1995). "Hurdle the Cross-functional Barriers to Strategic Change", Sloan Management Review 36 (3).

Jacob, J. and Duijn, Van J. (1972), "An Interregional Model of Economic Fluctuations" (Burgess Hill: Saxon House).

Lubashev, Y.A. (2013), "Strategic Trends in Regional Social Development" (SaintPetersburg: MFIN publishing house), p.176.

Malsagov, I.A. and Mironova, O.A. (2013), "The Concept of Control over the Completion of Strategic Objectives and the Achievement of Key Indicators of Strategic Development", Economic Sciences 12: pp. 32-38.

Malsagov, I.A. (2013), "Methodological Bases of Forming an Integrated System of Strategic Management Accounting, Analysis and Control", Problems of Economics and Law 6: pp. 98-102.

Matraeva, L.V. (2012), "Instruments for Assessing the Efficiency of Management of the Regional Social Development: Methodological Approaches and Calculation Results", (Moscow: Marketing) p. 160.

Neveykina, N.V. (2013), "The Economic Essence of Efficient Management of Regional Development", Economic Analysis: Theory and Practice 20 (323): pp. 31-36.

Oveshnikova, L.V. (2013), "Strategic Planning System for Entrepreneurial Activity", Industrial Policy at the Macro- and Macro-Levels: Multi-Author Monograph. In Ye. V. Sibirskaya (Eds.), (Voronezh: "Scientific Book" publishing and printing house) p. 128.

Piercy, N.F., Harris, L.C., Peters, L.D. and Lane, N. (1997), "Marketing Management, Market Strategy and Strategic Management: Domain Realignment and Redefinition", Journal of Strategic Marketing 5.

Porter, M. (1990), "The Competitive Advantage of Nations" (New York, NY McMillan press).

Pries, F. and Janszen, F. (1995), "Innovation in the Construction Industry: The Dominant Role in the Environment", Construction Management and Economics (Cheltenham: Edward Elgar Publisher).

Reading, C. (2002), "A Dynamic System for Improving Performance \& Competitive Advantage”, Strategic Business Planning (London: Kogan Page Ltd) p. 376. 
Rudenko, M.N. (2014), “Theoretical Aspects of Enterprises' Consolidation during Economic Instability”, Perm State University Bulletin. Economy Series 1 (20): pp.124-133.

Schoemaker, P. (1995), "Scenario Planning: A Tool for Strategic Thinking", Sloan Management Review 36 (2).

Schumpeter, J.A. (1934), “The Theory of Economic Development: An Inquiry into Profits, Capital, Credit, Interest, and the Business Cycle" (Piscataway, New Jersey: Transaction Publishers).

Sorvina, O.V. (2013), "Increasing the Efficiency of Managing Production Costs, based on Improving of the Enterprise's Supply with Resources", International Accounting 35 (281): 37-49.

Tazhitdinov, I.A. (2013), "Sub-Regional Approach to Managing Territorial Development: Methodology and Practice” (Ufa: Russian Academy of Sciences Ufa Scientific Center Institute of Socioeconomic Studies) p. 234.

Thompson, A.A. and Strickland, A.J. (1990), "Strategic Management" (Homewood: Irwin Inc.). 